\title{
Potential Jatropha Curcas (Jatropha Curcas L.) Germplasm by Exploration In Gorontalo Province Indonesia
}

\author{
Muhamad Rusliyadi, Ratna Tri Kumalasari, Phong Thanh Nguyen, Wahidah Hashim, Andino \\ Maseleno
}

\begin{abstract}
These day Jatrophacurcas is very popular crop as oil fuel substitution able to repaired so that its availability very required by society. A good seed source is required to support high production Jatrophacurcas in Indonesia. Seeds can be obtained by exploring natural habitat to understand genotypic variability and ecological suitability for Jatrophacurcas production. Activity of this exploration is to know genotype of variability at the same time identify the existence of accession potential of Jatrophacurcas in gorontalo province to be able to support development Jatrophacurcas in Gorontalo province. Exploration executed by collecting, germ plasma documentation and characterizations apart exist in Gorontalo province henceforth evaluate and conservation in Balittas (Indonesian Sweetener and fiber Research Institute) to be used breeding activity. Jatrophacurcas potency in gorontalo province can bear fruit during the year marked with can bear fruit at dry season, long lived long lived potency more than 60 year and there to resilience shading of which is showed ably bearing fruit. Jatrophacurcas local type in Gorontalo there is owning potency to be used upon which plant in supporting Jatrophacurcas development, come from selecting and only preserving crop fulfilling the above mentioned criterion able to be used as by seed plants.
\end{abstract}

Keywords : Exploration, Seed, Jatropha curcas, Gorontalo Province.

\section{INTRODUCTION}

Jatrophacurcas plant including the family Euphorbiaceae, a family with a rubber and cassava. The tree form of the shrub with a height of 1-7 m, irregularly branched. Cylindrical woody trunk release sap when injured. Leaves a single leaf, grooved, angled 3 or 5 , bone finger leaves with 5-7 primary bone, green leaf color (lower surface paler than the top). Petiole length

Revised Manuscript Received on July 22, 2019

Muhamad Rusliyadi, Ratna Tri Kumalasari, Phong Thanh Nguyen, Wahidah Hashim, Andino Maseleno

Polytechnic of Agricultural Development Yogyakarta-Magelang, Agricultural Extension and

Human Resource Development Agency, Ministry of Agriculture, Indonesia Agriculture Extension Officer, Agricultural and Food Security Office, Kebumen Regency,

Indonesia

Department of Project Management, Ho Chi Minh City Open University (HCMCOU), Vietnam.

Institute of Informatics and Computing Energy, Universiti Tenaga Nasional, Malaysia.

Corresponding author E-mail: m_rusliyadi@yahoo.com between 4-15 cm. Flowers greenish yellow, panicle-shaped form of compound interest, married one. Male flowers and female flowers appear in the series of cup-shaped tip of the stem or axillaries panicles. Fruit of the fruit is egg-shaped box, diameter of 2-4 cm, green when young and yellow when ripe. The distance divided 3-5 rooms each - each space is filled 1 seed. Bean-shaped oval, blackish brown color. These seeds that contain lots of oil with yield approximately $30-40 \%$. [1].

Jatrophacurcas L. has long been known by people in various regions in Indonesia, which since it was introduced by the Japanese in 1942's where people were ordered to plant Jatropha (Jatrophacurcas) as a garden fence. Some local name (local name) given to the plant Jatropha (Jatrophacurcas), among others Sundanese (JarakKosta, jarakbudeg), Java (JarakGundul, Jarak Pager), Nusa Tenggara (lulu mau, Pakukase, JarakPageh), Alor (kumannema), Maluku (aiHuwa Kamala, balacaikadoto) while in Gorontalo province own local communities named Binthalo. [2].

Amid the soaring price of fuel oil, the presence of castor seeds is considered to give new hope. Since the days of Japanese occupation more than 60 years ago castor oil has been known as an alternative to diesel oil. Now, with oil prices rising to U.S. \$ 66 per-barrel, like castor oil gaining momentum for the show itself. [3].

Performance of territory, topography, soils, water availability and climate have shaped the plant, especially the plant Jatrophacurcas to grow and adapt to specific locations. Usually cultivars or species that have been adapted with a good tolerance on local circumstances known to the local varieties [4].Cultivar is a distance of germ plasma is very important to the potential of each region in the province of Gorontalo different appearance so that need to be conserved.

Exploration activities aimed to identify the genetic diversity of morphology as well as identify any potential accession (Assessed production) Jatrophacurcas in the region Gorontalo to be able to support the development of Jatrophacurcas in the

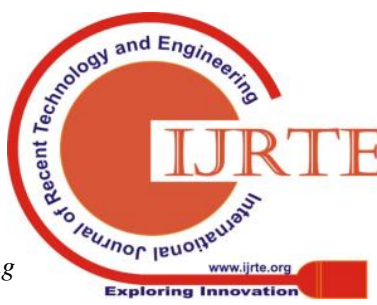


province of Gorontalo.

\section{RESEARCH METHODOLOGY}

Exploration activities carried out in December 2006. Areas to be explored consists of level II region of Bone County Bolango, Regency Gorontalo, Gorontalo City Boalemo District and less than 4 out of 5 Regional Level II in the Province of Gorontalo.

Exploration carried out by collecting, characterization and documentation of existing germplasm distance in the province of Gorontalo to the next to be evaluated and conserved in Balittas to be used further breeding activities.

The approach used a survey method in which the field before carrying out field activities are preceded by Pre Survey to collect data about the history and development locations and other information from the Department of Forestry Plantations and Gorontalo Province and the local community. Another form of survey material preparation prior to field survey with an inventory of materials and tools necessary.

Each district explored taking 8 points / samples. Determination of sample trees is done selectively used as a starting point of reference in the sampling of selected trees that have the appearance of heavy fruiting, flowering or the number of female flowers per-clusters quite a lot. According [5] dense fruit criteria are plants that bear fruit at least three bunches of clusters that each have 10 pieces or more. The selected trees are marked wire, recorded on the passport data, characterized, documented and taken seeds or roasts to be evaluated further in Balittas(Indonesian Sweetener and fiber Research Institute) Karangploso, Malang. Methods of data analysis used is descriptive analysis method and simple statistics.

\section{RESULTS AND DISCUSSION}

Exploration results showed that characteristics of local Jatrophadipropinsigorontalo almost the same morphological characteristics of the color red, green plant shoots, green leaf color and number of leaf indentation of five fruit. Other plants are found consists of 2 types of leafy plants and broadleaf narrow. Most of the plants found in the type of narrow leaved plants while the broad-leaf type found in the village leyato district south eastern city of Gorontalo town but has not been fruitful.

Jatropha (Jatrophacurcas) Gorontalo local also has the potential shade tolerant because of some samples was found in sample number 4 / BB - GTL, 7 / BB - GTL and 15 / KG - GTL is able to bear fruit in the dry season, although not so much. This gives a picture on a less than optimal conditions capable of fruiting, of the three samples which have the highest production Assessed on sample number $4 / \mathrm{BB}$ - GTL in toto village north Bone Bolango County Tilong Kabila.

Plants have a range in altitude tolerance grows large enough, from 0-1700 $\mathrm{m}$ asl [6]. Height varies from place sampling locations for each region taken from the beach about $4 \mathrm{~m}$ above sea level to undulating hills with the highest area of approximately $165 \mathrm{~m}$ above sea level, with different production variations.High places allegedly giving effect to the character spacing of crop production in the Province of Gorontalo. Samples obtained from the place that has a height of more than $100 \mathrm{~m}$ above sea level as much as 5 (sample) is the sample number $01 /$ BB - GTL (150 m asl), 16 / KB - GTL (140 m asl), 17 / KB - GTL (165 m asl), 26 / B - GTL (110 m asl), and 27 / B - GTL (120 m asl). Considering the age it can be seen in Table 1 that the sample number 17/KB-GTL show good performance with the number of fruits per bunch has as many as 8-18 fruit although the number of branches has not been too many (10 pieces).

The diversity of characters that crop performance indicated the distance is not too visible because virtually all the same. On top of all the color samples taken reddish green even if it differs not very real. Green leaf color all but the sample number $10 / \mathrm{KT}$ - GTL has a wider leaf than the other samples with a length of approximately $25 \mathrm{~cm}$ and $30 \mathrm{~cm}$ wide and almost all the leaves have grooves 5 pieces.

Age of plant samples taken varied from age 6 months to 63 years of age. Information age range of plants obtained from farmers or ownerswho provide forecast information when planted. The diversity of plant life indicates samples taken have the potential for long-lived and still bear fruit even in sample number $8 / \mathrm{BB}$ GTL plant has reached 60 years old but still productive fruiting can even reach $4.243 \mathrm{~kg}$ of planting.

Number of bunches of plants sampled distance has a varied range of 3-128 bunches. The range of the smallest three bunches were taken from samples with a variety of characters and still broadleaf flowering stage so that the maximum formation yet tnadan - bunches. Bunch is the formation of the fruit stalk which usually consists of several male and female flowers are pollinated itself (selfing).

Total fruit pertandan varies with the range - average between 60-20 units. Number of fruits pertandan this will affect the production of fruit cropping distance in broad fruitful union. The diversity of production potential is highly dependent on the biophysical condition of the plants grow, including altitude, rainfall, soil type and texture as well as the genetic potential that dilapang with different conditions.

Assessed production represents the estimated results of the 
Jatropha plantation which the calculation depends on the number of bunches and number of fruit in one season pertandan fruition. The diversity of the performance of production from the samples taken showed the highest yield potential obtained on samples 8 / BB - GTL located in the village of Bone BolangoPangguloBotupingge District. Yanng plant age reached 60 years with a canopy spread and very heavy in fruit. The spacing of plants begin to bear fruit at the age of 6 months and stabilized after the age of 5 years as for its economic life between the ages of 30-40 years [7].

Table 1. Character GermplasmJatrophacurcas Number Collection, Local Origin, High plant; Stem diameter, High Places, Age of plant, Branches, Bunch Number, Number of Fruit Per-Bunch, and Assessed Production Per-plant and Assessed production per unit area (ha) in Bone County Bolango, Gorontalo Province, 2006

\begin{tabular}{|c|c|c|c|c|c|c|c|c|c|c|c|c|c|}
\hline \multirow[b]{2}{*}{$\begin{array}{c}\text { Numb } \\
\text { er } \\
\text { Collec } \\
\text { tion }\end{array}$} & \multirow[b]{2}{*}{$\begin{array}{l}\text { Local } \\
\text { Origin }\end{array}$} & \multirow[b]{2}{*}{$\begin{array}{l}\text { High } \\
\text { plant } \\
(\mathrm{m})\end{array}$} & \multirow[b]{2}{*}{$\begin{array}{l}\text { Stem } \\
\text { diam } \\
\text { eter } \\
(\mathrm{cm})\end{array}$} & \multirow[b]{2}{*}{$\begin{array}{l}\text { High } \\
\text { Places } \\
\text { (m asl) }\end{array}$} & \multirow[b]{2}{*}{$\begin{array}{l}\text { Age of } \\
\text { plant } \\
\text { (year) }\end{array}$} & \multirow[b]{2}{*}{$\begin{array}{l}\text { Numb } \\
\text { r of } \\
\text { Branc } \\
\text { hes }\end{array}$} & \multirow[b]{2}{*}{$\begin{array}{l}\text { Numb } \\
\text { er of } \\
\text { Bunch }\end{array}$} & \multirow{2}{*}{$\begin{array}{c}\text { Num } \\
\text { ber } \\
\text { of } \\
\text { Fruit } \\
\text { Per- } \\
\text { Bunc } \\
\text { h } \\
\end{array}$} & \multirow[b]{2}{*}{$\begin{array}{l}\text { Assessed } \\
\text { Producti } \\
\text { on } \\
\text { Per-plan } \\
\mathrm{t}(\mathrm{g})\end{array}$} & \multicolumn{3}{|c|}{$\begin{array}{l}\text { Assessed production per unit area } \\
\left(\mathrm{Kg} \mathrm{ha}^{-1}\right)\end{array}$} & \multirow[b]{2}{*}{ Note } \\
\hline & & & & & & & & & & $\begin{array}{l}\text { Plant } \\
\text { spacin } \\
\text { g } \\
(2 \mathrm{X} 2 \\
\text { m) }\end{array}$ & $\begin{array}{c}\text { Plant } \\
\text { spacin } \\
\text { g } \\
(3 \mathrm{X} 3 \\
\text { m) }\end{array}$ & $\begin{array}{c}\text { Plant } \\
\text { spacing } \\
(1,5 \mathrm{X} 1,5 \mathrm{~m})\end{array}$ & \\
\hline $\begin{array}{l}01 / \\
\text { BB - } \\
\text { GTL }\end{array}$ & $\begin{array}{l}\text { Boidu } \\
\text { Village, } \\
\text { Bulango, } \\
\text { BoneBola } \\
\text { ngo }\end{array}$ & 3 & 2,5 & 150 & 63 & 36 & 71 & 0 & - & 0 & 0 & 0 & \\
\hline $\begin{array}{l}02 / \\
\text { BB - } \\
\text { GTL }\end{array}$ & $\begin{array}{l}\text { Boidu } \\
\text { Village, } \\
\text { Bulango, } \\
\text { BoneBola } \\
\text { ngo }\end{array}$ & 1 & 2 & 12 & 1 & 5 & 6 & 6-14 & 117 & 292,5 & 130 & 520 & $\begin{array}{l}\text { Still } \\
\text { Flowering }\end{array}$ \\
\hline $\begin{array}{l}03 / \\
\text { BB - } \\
\text { GTL }\end{array}$ & $\begin{array}{l}\text { TotoUtara } \\
\text { Village, } \\
\text { Tilong } \\
\text { Kabila, } \\
\text { BoneBola } \\
\text { ngo }\end{array}$ & 2 & 3,5 & 10 & 2 & 7 & 14 & $8-20$ & 382 & 955,5 & 424,7 & 1698,7 & \\
\hline $\begin{array}{l}04 / \\
\text { BB - } \\
\text { GTL }\end{array}$ & $\begin{array}{l}\text { TotoUtara } \\
\text { Village, } \\
\text { Tilong } \\
\text { Kabila, } \\
\text { BoneBola } \\
\text { ngo }\end{array}$ & 2 & 3 & 10 & 2 & 8 & 13 & $7-19$ & 330 & 823,8 & 366,2 & 1464,7 & \\
\hline $\begin{array}{l}05 / \\
\text { BB - } \\
\text { GTL }\end{array}$ & $\begin{array}{l}\text { Bongopini } \\
\text { Village, } \\
\text { Tilong } \\
\text { Kabila, } \\
\text { Bone } \\
\text { Bolango } \\
\end{array}$ & 2,5 & 2,8 & 12 & 2 & 11 & 10 & 6-16 & 234 & 585 & 260 & 1040 & $\begin{array}{l}\text { Plants in the } \\
\text { shade }\end{array}$ \\
\hline $\begin{array}{l}06 / \\
\text { BB - } \\
\text { GTL }\end{array}$ & $\begin{array}{l}\text { Moutong } \\
\text { Village, } \\
\text { Tilong } \\
\text { kabila, } \\
\text { Bone } \\
\text { Bolango }\end{array}$ & 2 & 2 & 10 & 2 & 8 & 6 & $7-19$ & 152 & 380,3 & 169 & 676 & \\
\hline $\begin{array}{l}07 / \\
\text { BB - } \\
\text { GTL }\end{array}$ & $\begin{array}{l}\text { Buwata } \\
\text { Village, } \\
\text { Botupingg } \\
\text { e, Bone } \\
\text { Bolango } \\
\end{array}$ & 2,5 & 2 & 10 & 2 & 6 & 5 & $3-5$ & 39 & 97,5 & 43,3 & 173,3 & \\
\hline $\begin{array}{l}08 / \\
\text { BB - } \\
\text { GTL }\end{array}$ & $\begin{array}{l}\text { Panggulo } \\
\text { Village, } \\
\text { Botupingg } \\
\text { e, Bone } \\
\text { Bolango }\end{array}$ & 4 & 30 & 3 & 60 & 34 & 128 & $6-28$ & 4243 & 10608 & $\begin{array}{l}4714, \\
7\end{array}$ & 18858,7 & $\begin{array}{l}\text { Plants in the } \\
\text { shade }\end{array}$ \\
\hline & Average & 2,4 & 6,0 & 27,1 & 16,8 & 14,4 & 31,6 & 10,3 & 785,3 & $\begin{array}{c}1717 \\
8\end{array}$ & 763,5 & 3053,9 & \\
\hline & STDev & 0,9 & 9,7 & 49,7 & 27,6 & 12,9 & 44,7 & 6,3 & 1529,4 & $\begin{array}{c}3607 \\
4\end{array}$ & $\begin{array}{c}1603, \\
3\end{array}$ & 6413,3 & \\
\hline
\end{tabular}


Table 2. Character GermplasmJatrophacurcas Number Collection, Local Origin, High plant; Stem diameter, High Places, Age of plant, Branches, Bunch Number, Number of Fruit Per-Bunch, and Assessed Production Per-plant and Assessed production per unit area (ha) in Bone County Bolango, Gorontalo Province, 2006

\begin{tabular}{|c|c|c|c|c|c|c|c|c|c|c|c|c|c|}
\hline \multirow[b]{2}{*}{$\begin{array}{l}\text { Number } \\
\text { Collectio } \\
\quad \mathrm{n}\end{array}$} & \multirow[b]{2}{*}{ Local Origin } & \multirow[b]{2}{*}{$\begin{array}{l}\text { High } \\
\text { plant } \\
\text { (m) }\end{array}$} & \multirow[b]{2}{*}{$\begin{array}{l}\text { Stem } \\
\text { diamet } \\
\text { er }(\mathrm{cm})\end{array}$} & \multirow{2}{*}{$\begin{array}{l}\text { High } \\
\text { Plac } \\
\text { es (m } \\
\text { asl) }\end{array}$} & \multirow{2}{*}{$\begin{array}{l}\text { Age } \\
\text { of } \\
\text { plant } \\
\text { (year } \\
\text { ) }\end{array}$} & \multirow{2}{*}{$\begin{array}{l}\text { Num } \\
\text { br of } \\
\text { Bran } \\
\text { ches }\end{array}$} & \multirow[b]{2}{*}{$\begin{array}{l}\text { Numbe } \\
\text { r of } \\
\text { Bunch }\end{array}$} & \multirow{2}{*}{$\begin{array}{c}\text { Number } \\
\text { of Fruit } \\
\text { Per-Bunc } \\
\text { h }\end{array}$} & \multirow{2}{*}{$\begin{array}{c}\text { Assessed } \\
\text { Productio } \\
\text { n } \\
\text { Per-plant } \\
\text { (g) }\end{array}$} & \multicolumn{3}{|c|}{$\begin{array}{l}\text { Assessed production per unit area } \\
\left(\mathrm{Kg} \mathrm{ha}^{-1}\right)\end{array}$} & \multirow[b]{2}{*}{ Note } \\
\hline & & & & & & & & & & $\begin{array}{c}\text { Plant } \\
\text { spacing } \\
(2 \mathrm{X} 2 \mathrm{~m})\end{array}$ & $\begin{array}{c}\text { Plant } \\
\text { spacing } \\
(3 \mathrm{X} 3 \mathrm{~m})\end{array}$ & $\begin{array}{c}\text { Plant } \\
\text { spacing } \\
(1,5 \mathrm{X} 1 \\
, 5 \mathrm{~m}) \\
\end{array}$ & \\
\hline $\begin{array}{l}11 / \mathrm{KB}- \\
\text { GTL }\end{array}$ & $\begin{array}{l}\text { Huntu Village, } \\
\text { Batu Daa, Kab. } \\
\text { Gorontalo }\end{array}$ & 2,5 & 16 & 5 & 10 & 22 & 17 & $6-16$ & 365 & 911,6 & 405,2 & 1620,7 & $\begin{array}{l}\text { New } \\
\text { flowering } \\
\text { plants } \\
\text { (leaf } \\
\text { width) }\end{array}$ \\
\hline $\begin{array}{l}12 / \mathrm{KB}- \\
\mathrm{GTL}\end{array}$ & $\begin{array}{l}\text { Tambongo Timur } \\
\text { Village, Batu Daa, } \\
\text { Kab. Gorontalo }\end{array}$ & 2 & 5 & 12 & 3 & 86 & 27 & $5-17$ & 579 & 1447,8 & 643,5 & 2574 & $\begin{array}{l}\text { New } \\
\text { flowering } \\
\text { plants }\end{array}$ \\
\hline $\begin{array}{l}13 / \mathrm{KB}- \\
\text { GTL }\end{array}$ & $\begin{array}{l}\text { Kaliyoso Village, } \\
\text { Bongo Meme, } \\
\text { Kab. Gorontalo }\end{array}$ & 2,5 & 10 & 25 & 15 & 38 & 35 & $7-13$ & 683 & 1706,3 & 758,3 & 3033,3 & \\
\hline $\begin{array}{l}\text { 14/ KB - } \\
\text { GTL }\end{array}$ & $\begin{array}{l}\text { Dulamayo, } \\
\text { Bongomeme, Kab. } \\
\text { Gorontalo }\end{array}$ & 1,5 & 20 & 25 & 15 & 14 & 14 & $10-20$ & 410 & 1023,8 & 455 & 1820 & \\
\hline $\begin{array}{l}15 / \mathrm{KB}- \\
\text { GTL }\end{array}$ & $\begin{array}{l}\text { Bongo Hulawa } \\
\text { Village, } \\
\text { Bongomeme, Kab. } \\
\text { Gorontalo }\end{array}$ & 4 & 32 & 90 & 25 & 46 & 40 & $1-3$ & 156 & 390 & 173,3 & 693,3 & \\
\hline $\begin{array}{l}\text { 16/ KB - } \\
\text { GTL }\end{array}$ & $\begin{array}{l}\text { Otopade Village, } \\
\text { Bongo Meme, } \\
\text { Kab. Gorontalo }\end{array}$ & 2 & 7,5 & 140 & 3 & 11 & 11 & $11-18$ & 322 & 804,4 & 357,5 & 1430 & $\begin{array}{l}\text { Plants in } \\
\text { the shade }\end{array}$ \\
\hline $\begin{array}{l}17 / \mathrm{KB}- \\
\text { GTL }\end{array}$ & $\begin{array}{l}\text { Batulayar Village, } \\
\text { Bongomeme, Kab. } \\
\text { Gorontalo }\end{array}$ & 1 & 7 & 165 & 1 & 10 & 10 & 8-18 & 254 & 633,8 & 281,7 & 1126,7 & $\begin{array}{l}\text { Fruit } \\
\text { shape bit } \\
\text { wide }\end{array}$ \\
\hline $\begin{array}{l}\text { 18/ KB - } \\
\text { GTL }\end{array}$ & $\begin{array}{l}\text { Mulyonegoro } \\
\text { Village, Pulubala, } \\
\text { Kab. Gorontalo }\end{array}$ & 2 & 7 & 100 & 6 & 15 & 8 & $4-6$ & 78 & 195 & 86,7 & 346,7 & \\
\hline $\begin{array}{l}21 / \mathrm{KB}- \\
\text { GTL }\end{array}$ & $\begin{array}{l}\text { Lakeya Village, } \\
\text { Tolangohula, Kab } \\
\text { Gorontalo }\end{array}$ & 1,1 & 3 & 50 & 2 & 13 & 13 & $6-12$ & 228 & 570,4 & 253,5 & 1014 & \\
\hline & Average & 2,1 & 8,8 & 68,0 & 8,9 & 28,3 & 19,4 & 10,1 & 341,7 & 853,7 & 379,4 & 1517,6 & \\
\hline & STDev & 0,9 & 5,7 & 58,3 & 8,1 & 25,1 & 11,7 & 4,3 & 194,6 & 486,3 & 216,1 & 864,6 & \\
\hline
\end{tabular}


Table 3. Character GermplasmJatrophacurcas Number Collection, Local Origin, High plant; Stem diameter, High Places, Age of plant, Branches, Bunch Number, Number of Fruit Per-Bunch, and Assessed Production Per-plant and Assessed production per unit area (ha) in Bone Bolango, Gorontalo Province, 2006

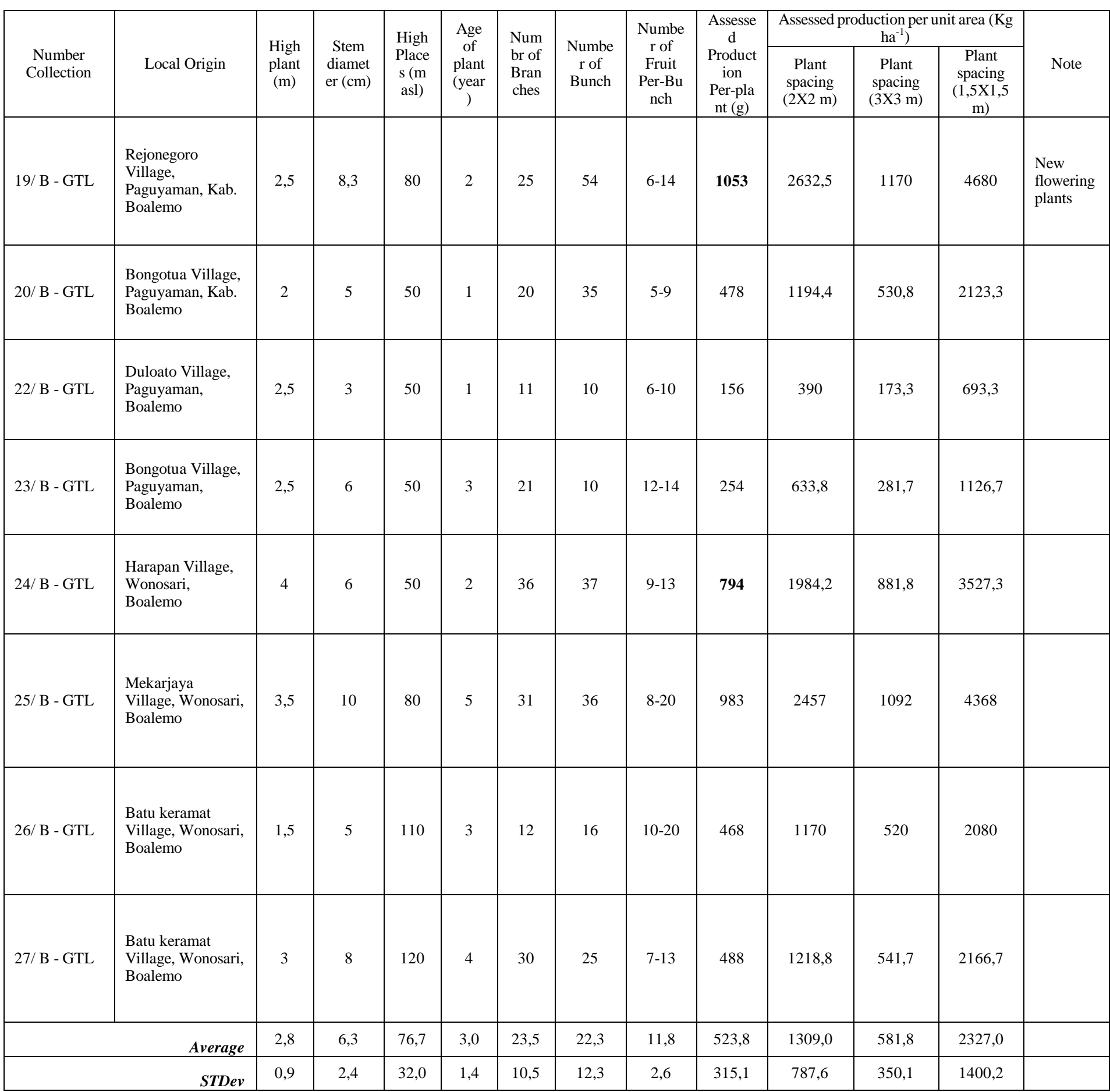


Table 4. Character GermplasmJatrophacurcas Number Collection, Local Origin, High plant; Stem diameter, High Places, Age of plant, Branches, Bunch Number, Number of Fruit Per-Bunch, and Assessed Production Per-plant and Assessed production per unit area (ha) in Bone County Bolango, Gorontalo Province, 2006

\begin{tabular}{|c|c|c|c|c|c|c|c|c|c|c|c|c|c|}
\hline \multirow[b]{2}{*}{$\begin{array}{l}\text { Number } \\
\text { Collection }\end{array}$} & \multirow[b]{2}{*}{ Local Origin } & \multirow[b]{2}{*}{$\begin{array}{l}\text { High } \\
\text { plant } \\
\text { (m) }\end{array}$} & \multirow[b]{2}{*}{$\begin{array}{l}\text { Stem } \\
\text { diam } \\
\text { eter } \\
(\mathrm{cm})\end{array}$} & \multirow[b]{2}{*}{$\begin{array}{l}\text { High } \\
\text { Place } \\
\text { s (m } \\
\text { asl) }\end{array}$} & \multirow{2}{*}{$\begin{array}{l}\text { Age } \\
\text { of } \\
\text { plant } \\
\text { (year } \\
\text { ) }\end{array}$} & \multirow[b]{2}{*}{$\begin{array}{l}\text { Numbr } \\
\text { of } \\
\text { Branch } \\
\text { es }\end{array}$} & \multirow[b]{2}{*}{$\begin{array}{l}\text { Num } \\
\text { ber of } \\
\text { Bunc } \\
h\end{array}$} & \multirow[b]{2}{*}{$\begin{array}{c}\text { Number } \\
\text { of Fruit } \\
\text { Per-Bunc } \\
\text { h }\end{array}$} & \multirow{2}{*}{$\begin{array}{c}\text { Assesse } \\
\text { d } \\
\text { Producti } \\
\text { on } \\
\text { Per-plan } \\
\text { t (g) }\end{array}$} & \multicolumn{3}{|c|}{$\begin{array}{l}\text { Assessed production per unit area }(\mathrm{Kg} \\
\left.\mathrm{ha}^{-1}\right)\end{array}$} & \multirow[b]{2}{*}{ Note } \\
\hline & & & & & & & & & & $\begin{array}{c}\text { Plant } \\
\text { spacing } \\
(2 \mathrm{X} 2 \mathrm{~m})\end{array}$ & $\begin{array}{l}\text { Plant } \\
\text { spacing } \\
(3 \mathrm{X} 3 \\
\mathrm{m})\end{array}$ & $\begin{array}{c}\text { Plant } \\
\text { spacing } \\
(1,5 \mathrm{X} 1,5 \mathrm{~m})\end{array}$ & \\
\hline 28/ KT - GTL & $\begin{array}{l}\text { Limba B } \\
\text { Village, Kota } \\
\text { Selatan, Kota } \\
\text { Gorontalo }\end{array}$ & 3 & 7 & 5 & 2 & 28 & 28 & $6-16$ & 601 & 1501,5 & 667,3 & 2669,3 & \\
\hline 29/ KT - GTL & $\begin{array}{l}\text { Donggala } \\
\text { Village, Kota } \\
\text { Selatan, Kota } \\
\text { Gorontalo }\end{array}$ & 3 & 2 & 5 & 10 & 58 & 38 & $7-13$ & 741 & 1852,5 & 823,3 & 3293,3 & \\
\hline 30/ KT - GTL & $\begin{array}{l}\text { Tenilow } \\
\text { Village, Kota } \\
\text { Barat, Kota } \\
\text { Gorontalo }\end{array}$ & 2 & 2 & 6 & 3 & 20 & 19 & $2-4$ & 111 & 277,9 & 123,5 & 494 & \\
\hline 31/ KT - GTL & $\begin{array}{l}\text { endaKalengko } \\
\text { ngan Village } \\
\text { Kota Selatan, } \\
\text { Kota } \\
\text { Gorontalo }\end{array}$ & 1,5 & 12 & 5 & 4 & 18 & 12 & $6-10$ & 187 & 468 & 208 & 832 & $\begin{array}{l}\text { New flowering } \\
\text { plants }\end{array}$ \\
\hline 32/ KT - GTL & $\begin{array}{l}\text { Wumialo } \\
\text { Village, Kota } \\
\text { Tengah, Kota } \\
\text { Gorontalo } \\
\end{array}$ & 2,5 & 11 & 3 & 3 & 20 & 25 & $6-16$ & 536 & 1340,6 & 595,8 & 2383,3 & \\
\hline 33/ KT - GTL & $\begin{array}{l}\text { Wongkaditi } \\
\text { Timur } \\
\text { Village, Kota } \\
\text { Utara, Kota } \\
\text { Gorontalo }\end{array}$ & 4 & 12 & 8 & 4 & 35 & 17 & $6-20$ & 431 & 1077,4 & 478,8 & 1915,3 & \\
\hline 09/ KT - GTL & $\begin{array}{l}\text { Leyato } \\
\text { Selatan } \\
\text { Village, Kota } \\
\text { Timur, Kota } \\
\text { Gorontalo }\end{array}$ & 2 & 5 & 10 & 4 & 9 & 8 & $5-18$ & 187 & 468 & 208 & 832 & \\
\hline 10/ KT - GTL & $\begin{array}{l}\text { Leyato } \\
\text { Selatan } \\
\text { Village, Kota } \\
\text { Timur, Kota } \\
\text { Gorontalo }\end{array}$ & 1 & 2 & 10 & 0,5 & 4 & 3 & 0 & 0 & 0 & 0 & 0 & \\
\hline & Average & 2,4 & 6,6 & 6,5 & 3,8 & 24,0 & 18,8 & 8,4 & 349,3 & 733,3 & 388,1 & 1552,4 & \\
\hline & STDev & 0,9 & 4,5 & 2,6 & 2,8 & 16,8 & 11,4 & 4,6 & 264,5 & 572,0 & 293,8 & 1175,2 & \\
\hline
\end{tabular}

The potential of other plants found in sample number 19 / B - GTL production can be quite high at $1,053 \mathrm{~kg}$ of plant age of approximately 2 years with a rather large number of bunches and number of branches 54 only 25 pieces. It can be seen - average each branch to form two pieces of fruit bunches with an average of about 6-14 pieces. This sample is the best sample of Boalemo District with the condition of the plants used as fences near waterways. Samples of other collections that have good potential that is $17 / \mathrm{KG}$ GTL is located in the village BatulayarBongomemeGorontalo District. From a young age of the plant about a year but quite a lot perbuah range 8-18 fruits and visual appearance has a lot of ripe fruit (yellow) and some have been blackened (dry), Assessed production is not too high it is because the number of branches formed but still a little 10 pieces of these branches produce fruit bunches all. Potential production is expected from the plant Jatropha (Jatrophacurcas) in which each branch to form bunches of fruit can be more than one.
In table $1,2 \quad 3$ and 4 describe the production Assessed broad unity in each district is shown in several plant spacing when cultured with either course with a different population. The result is the production Assessed estimates of crop production, with a population of plants when grown with regular spacing.

For optimum plant spacing used for the cultivation of a distance of $2 \times 2 \mathrm{~m}$ Assessed highest production on sample number 8 / BB - GTL as much as $10608 \mathrm{~kg}$ ha- 1 or the equivalent of 10.6 tons ha- 1 . This result is of course a picture when the plants produce fruit the same as the samples taken. The production that was quite high at a spacing of $2 \times 2 \mathrm{~m}$ obtained on the sample number 19 / B - GTL is able to produce 2632.5 $\mathrm{kg}$ ha-1, equivalent to 2.6 tons ha-1. This is supported by [8] that the optimal planting jatropha population is 2 x $2 \mathrm{~m}$ with a population of 2500 per hectare. Results the results of other studies showed that the population in 1111 to 2,500 plants per hectare gives good results [9]. 
At optimal conditions of plants grown by a spacing distance of $3 \times 3 \mathrm{~m}$ which would reduce the plant population is broad unity so that the Assessed production be greatly reduced. Assessed range of production in this population of about 1111 plants per hectare reaches various weights of 130 to $4714.7 \mathrm{~kg}$ ha-1. With a spacing of this magnitude from the samples taken are still very high - average 2.4 tons per hectare. With closer spacing of $1.5 \times 1.5 \mathrm{~m}$ with a total population of around 4444 plant crop production range of 520 to $18858.7 \mathrm{~kg}$ ha-1 the average - rating of 9689.35 $\mathrm{kg} / \mathrm{ha}$.

Table 5. Average for each region where exploration for the variable Plant Height $(\mathrm{m})$, stem diameter $(\mathrm{cm})$, Height place $(\mathrm{m}$ above sea level), Age Plant (Year), Amount Branch and amount of bunch.

\begin{tabular}{|l|c|c|c|c|c|c|}
\hline \multicolumn{1}{|c|}{ Regency } & $\begin{array}{c}\text { Plant } \\
\text { Height }(\mathrm{m})\end{array}$ & $\begin{array}{c}\text { Stem } \\
\text { diameter } \\
(\mathrm{cm})\end{array}$ & $\begin{array}{c}\text { Height } \\
\text { place } \\
(\mathrm{m} \text { asl) }\end{array}$ & $\begin{array}{c}\text { Age Plant } \\
\text { (year) }\end{array}$ & $\begin{array}{c}\text { Amount } \\
\text { branch }\end{array}$ & $\begin{array}{c}\text { Amount } \\
\text { bunch }\end{array}$ \\
\hline Bone Bolango Regency & 2,4 & 6,0 & 27,1 & 16,8 & 14,4 & 31,6 \\
\hline $\begin{array}{l}\text { KabupatenGorontalo } \\
\text { Regency }\end{array}$ & 2,1 & 8,8 & 68,0 & 8,9 & 28,3 & 19,4 \\
\hline Boalemo Regency & 2,8 & 6,3 & 76,7 & 3,0 & 23,5 & 22,3 \\
\hline Gorontalo Municipality & 2,4 & 6,6 & 6,5 & 3,8 & 24,0 & 18,8 \\
\hline Average & 2,4 & 6,9 & 44,6 & 8,1 & 22,6 & 23,0 \\
\hline STDev & 0,3 & 1,3 & 33,3 & 6,3 & 5,9 & 5,9 \\
\hline
\end{tabular}

Each district in Gorontalo whose location is an area of exploration showed mixed results on several variablesIn the parameters plant height ranging from 2.1 to 2.8 meters on which the district Boalemo have the highest accession. Stem diameter also shows each district on a range of values $6.3 \mathrm{~cm}$ to $8.8 \mathrm{~cm}$. At the altitude varies or fluctuates with the value of more than one standard deviation in the district where Boalemo has the highest elevation sites. Age of plants, number of branch and show the differences fluctuated bunches in each district, especially in the Regency Bone Bolango because it was found accession Jatropha (Jatrophacurcas), a 60-year-old.

Table 6. Average for each region where exploration for variable-number of fruits per bunch, Assessed production per plant (g) and Assessed production per ha $(\mathrm{kg})$.

\begin{tabular}{|c|c|c|c|c|c|}
\hline \multirow[b]{2}{*}{ Regency } & \multirow{2}{*}{$\begin{array}{l}\text { The number of } \\
\text { fruits per bunch }\end{array}$} & \multirow{2}{*}{$\begin{array}{c}\text { Assessed } \\
\text { production } \\
\text { per plant. (g) }\end{array}$} & \multicolumn{3}{|c|}{ Assessed production per ha $(\mathrm{kg})$} \\
\hline & & & $\begin{array}{l}\text { Spacing } \\
(2 \times 2 \mathrm{~m})\end{array}$ & $\begin{array}{l}\text { Spacing } \\
(3 \times 3 \mathrm{~m})\end{array}$ & $\begin{array}{c}\text { Spacing } \\
(1,5 \mathrm{X} 1,5 \mathrm{~m})\end{array}$ \\
\hline Bone Bolango Regency & 10,3 & 785,3 & 1717,8 & 763,5 & 3053,9 \\
\hline $\begin{array}{l}\text { KabupatenGorontalo } \\
\text { Regency }\end{array}$ & 10,1 & 341,7 & 853,7 & 379,4 & 1517,6 \\
\hline Boalemo Regency & 11,8 & 523,8 & 1309,0 & 581,8 & 2327,0 \\
\hline Gorontalo Municipality & 8,4 & 349,3 & 733,3 & 388,1 & 1552,4 \\
\hline Means & 10,1 & 500,0 & 1153,5 & 528,2 & 2112,7 \\
\hline STDev & 1,4 & 208,0 & 450,6 & 182,6 & 730,3 \\
\hline
\end{tabular}

Assessed production of Jatropha (Jatrophacurcas), which is found in every district has a high level of variation where the highest score in the district Bone Bolango. This shows the district has a potential Bone BolangoJatrophacurcas is better compared to other districts.

The productivity level of the reported range of plants varies widely abroad [10]. reported the results of Jatropha (Jatrophacurcas) in Paraguay 3-4 tonnes ha-1 at the age of 7-9 years, in Nicaragua and in Mali respectively 5.0 and 2.8 tons ha-1 [7], while in Thailand 2.15 tons ha-1 (Ishii and Takeuchi in [10], As for the varieties that exist in Indonesia such as IP-1P production potential of the first year from 0.23 to 0.3 tons ha- 1 , the fifth year of 4-5 tons ha- 1 and recommended for wet climates, varieties of IP production potential year-1M first from 0.2 to 0.3 tons ha- 1 , the fifth year 4-5 tons ha-1 and recommended for temperate climates and dry, the variety of IP-1A first-year production potential from 0.27 to 0.3 tons ha- 1 , in the fifth year 4-5 tons ha-1 and is recommended for dry climates [11], So if we look at some of the information obtained from the exploration compared with the level of productivity than other countries and high yielding varieties in Indonesia is much higher but it needs further research in plant material that can be in Gorontalo at planting in other areas.

\section{CONCLUSION}

Diversity

Jatropha 
(Jatrophacurcas) dipropinsiGorontalo local genetic diversity have relatively similar in morphology, both in leaf color, leaf color and number of grooves on the leaf but more production variables defined in the environmental conditions where the distance grew. Potential of JatrophaCurcas (Jatrophacurcas) in Gorontalo province is able to bear fruit throughout the year which was marked by being able to bear fruit in the dry season, the potential for long-lived a long life of more than 60 years and have shown resilience to the shade with the ability to bear fruit.

Jatrophacurcas a local species in Bone Bolango regency of Gorontalo has the potential to be used as planting material in supporting the development of Jatrophacurcas, the home is the selection and choose only plants that meet the above criteria that can be used as seed.

\section{REFERENCES}

[1] Prospective Local Resources Bioenergy on SISTEKNAS DevelopmentDeputy, Ministry of Research and Technology, PuspiptekSerpong, 14 to 15 September 2005.

[2] Akuba, R.H. 2005. Jatropha Cultivation. Gorontalo Post, October 3, 2005, 7 .

[3] Duryatmo, S. 2005. Future Fuel Vehicles. Trubus Magazine June 2005 edition of 427 XXXVI. P. 28-29. TrubusSwadaya.

[4] Hawkes, J.G. 1980. Crop Genetic Resources Field Collection Manual. Dept. Of Plant Biology. Univ. Of Birmingham, England.

[5] Mahmud, Z., et al. 2006. Plant Technical Culture Jatropha. Proceedings of Workshop on Jatropha (Jatrophacurcas) Puslitbangbun 11 April 2006.

[6] Allorerung, D., Mahmud, Z., A. Arivin R., Dedi, S. E. and Anny, M. 2006. Climate and Land Suitability Map Distance (Jatrophacurcas L.). Proceedings of Workshop on Jatropha (Jatrophacurcas) Puslitbangbun 11 April 2006.

[7] Henning, R.K. 2004. The Jatropha System. Economy and dissemination strategy.International Conference of Renewable Energy. Bonn, Germany, 14 June 2004.

[8] Ratree, S., 2004. A Preliminary Study On Physic Nut (Jatrophacurcas L.) In Thailand. Pakistan Journal of Biological Sciences 7: 1620-1623.

[9] Heller, J., 1996. Physic Nut. JatrophaCurcas L. Promoting The Use Of Conservation And Underutilized And Neglected Crops. 1. Institute Of Plant Genetics And Crops Plant Research, Gatersleben / International Plant Genetic Resources Institute, Rome.

[10] Hasnam and Hartati, R. S. 2006. Providing Superior Seed Jatropha Plant (Jatrophacurcas L.). Proceedings of Workshop on JatrophaPuslitbangbun 11 April 2006.

[11] SinarTani. 2007. Superior Seed Jatropha (Jatrophacurcas L.). P. 16 Edition 27 December to 2 January 2007 No. 3181 Year XXXVII. 